\title{
Author Correction: TurbolD-based proximity labeling reveals that UBR7 is a regulator of N NLR immune receptor-mediated immunity
}

\author{
Yongliang Zhang (D), Gaoyuan Song, Neeraj K. Lal, Ugrappa Nagalakshmi, Yuanyuan Li (D), Wenjie Zheng, Pin- \\ jui Huang, Tess C. Branon, Alice Y. Ting, Justin W. Walley (1) \& Savithramma P. Dinesh-Kumar
}

Correction to: Nature Communications https://doi.org/10.1038/s41467-019-11202-z, published online 19 July 2019.

The original version of the Supplementary Information associated with this Article contained an error in Supplementary Fig. 8 in which panel $c$ was inadvertently duplicated from panel b. This panel was a graphical summary of data presented in Supplementary Data 2 which was correct at the time of publication.

The HTML has been updated to include a corrected version of the Supplementary Information.

Published online: 21 October 2021

\section{Additional information}

Supplementary information The online version contains supplementary material available at https://doi.org/10.1038/s41467-021-26441-2. \begin{abstract}
reproduction in any medium or format, as long as you give appropriate credit to the original author(s) and the source, provide a link to the Creative Commons license, and indicate if changes were made. The images or other third party material in this article are included in the article's Creative Commons license, unless indicated otherwise in a credit line to the material. If material is not included in the article's Creative Commons license and your intended use is not permitted by statutory regulation or exceeds the permitted use, you will need to obtain permission directly from the copyright holder. To view a copy of this license, visit http://creativecommons.org/licenses/by/4.0/.
\end{abstract}

(c) (i) Open Access This article is licensed under a Creative Commons Attribution 4.0 International License, which permits use, sharing, adaptation, distribution and

(c) The Author(s) 2021 